\title{
Teaching NeuroImages: Cerebral syphilitic gumma with numerous spirochetes in immunohistochemical staining
}

Yasuhiro Kuroi, MD, Shigeru Tani, MD, PhD, Makoto Shibuya, MD, PhD, and Hidetoshi Kasuya, MD, PhD Neurology ${ }^{\circledR}$ 2018;90:e818-e819. doi:10.1212/WNL.0000000000005029
Correspondence

Dr. Kuroi

kuroi.yasuhiro@twmu.ac.jp

Figure 1 Pathologic images

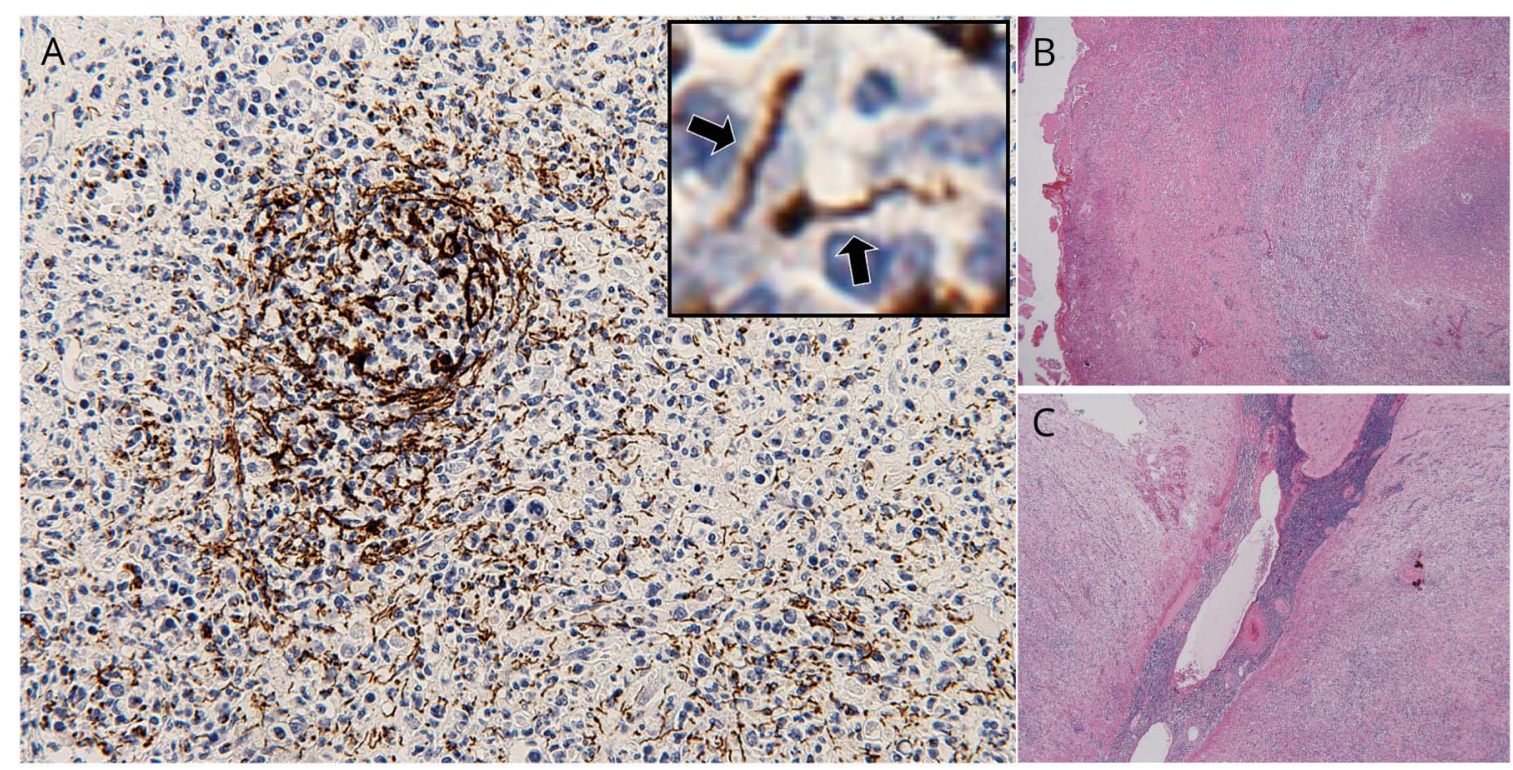

(A) Immunostaining using anti-Treponema pallidum antibody demonstrates numerous perivascular spirochetes (original magnification $\times 40$ ). (B, C) Hematoxylin \& eosin staining reveals gumma, composed of granulation tissue and massive necrosis accompanied by marked inflammatory cell infiltration, and meningitis with numerous lymphoplasmacytes accompanied by some occluded vessels (original magnification: B $\times 2.5, C \times 4$ ).

A 62-year-old HIV-negative man without any relevant medical history had extramarital sex once 3 years before admission. A malignant tumor-like lesion was found on brain MRI when he came to our clinic with headache (figures 1 and 2). We removed the tumor and immunohistochemical staining revealed numerous spirochetes. Postoperative antibacterial agent therapy significantly diminished the edematous lesion. The initial 155.6-fold higher serum rapid plasma reagin (RPR), 40,960-fold higher Treponema pallidum hemagglutination, 1,280-fold higher fluorescent treponemal antibody absorption test, and 2.2-fold higher CSF RPR levels gradually decreased over 6 months. Cerebral syphilitic gumma usually occurs $>10$ years after contracting syphilis. ${ }^{1}$ Although it is difficult to detect single spirochetes with immunohistochemical staining, ${ }^{2}$ aggressive cases may exhibit many spirochetes.

\section{MORE ONLINE}

$\rightarrow$ Teaching slides:

http://links.lww.com/WNL/A203

From the Department of Neurosurgery (Y.K., S.T., H.K.), Tokyo Women's Medical University Medical Center East; and Central Laboratory (M.S.), Hachioji Medical Center, Tokyo Medical University, Japan.

Go to Neurology.org/N for full disclosures. Funding information and disclosures deemed relevant by the authors, if any, are provided at the end of the article. 


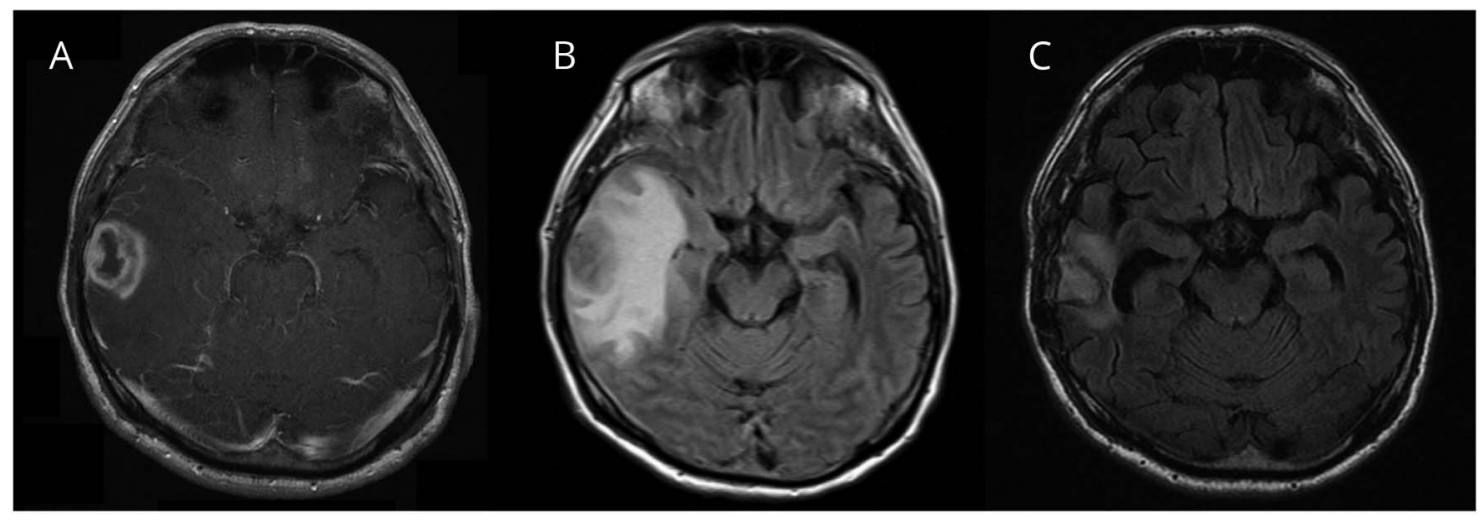

(A) Axial enhanced T1-weighted image and (B) fluid-attenuated inversion recovery image reveal ring-enhanced lesion with substantial edema at the right temporal lobe. (C) Three months after tumor removal and postoperative antibacterial therapy (penicillin G 6,000,000 U/d for 14 days and amoxicillin 4,000 $\mathrm{mg} / \mathrm{d}$ for 14 days), the lesion shows substantial improvement.

\section{Author contributions}

Yasuhiro Kuroi: main surgeon, describing manuscript. Shigeru Tani: assistant operator. Makoto Shibuya: pathologic examination and assessment. Hidetoshi Kasuya: assistant operator, critical revision of the manuscript for important intellectual content.

\section{Study funding}

No targeted funding reported.

\section{Disclosure}

The authors report no disclosures relevant to the manuscript. Go to Neurology.org/N for full disclosures.

\section{References}

1. Clark EG, Danbolt N. The Oslo study of the natural history of untreated syphilis: an epidemiologic investigation based on a restudy of the Boeck-Bruusgaard material; a review and appraisal. J Chronic Dis 1955;2:311-344.

2. Zhang L, Zhou Y, Chen J, et al. A case of a cerebral syphilitic gumma developed in a few months mimicking a brain tumor in a human immunodeficiency virus-negative patient. Br J Neurosurg 2016;31:481-483. 


\section{Neurology}

\section{Teaching NeuroImages: Cerebral syphilitic gumma with numerous spirochetes in immunohistochemical staining \\ Yasuhiro Kuroi, Shigeru Tani, Makoto Shibuya, et al. \\ Neurology 2018;90;e818-e819 \\ DOI 10.1212/WNL.0000000000005029}

This information is current as of February 26, 2018

\section{Updated Information \&} Services

References

Subspecialty Collections

Permissions \& Licensing

Reprints including high resolution figures, can be found at: http://n.neurology.org/content/90/9/e818.full

This article cites 2 articles, 0 of which you can access for free at: http://n.neurology.org/content/90/9/e818.full\#ref-list-1

This article, along with others on similar topics, appears in the following collection(s):

Bacterial infections

http://n.neurology.org/cgi/collection/bacterial_infections Meningitis

http://n.neurology.org/cgi/collection/meningitis

Information about reproducing this article in parts (figures,tables) or in its entirety can be found online at:

http://www.neurology.org/about/about_the_journal\#permissions

Information about ordering reprints can be found online:

http://n.neurology.org/subscribers/advertise

Neurology ${ }^{\circledR}$ is the official journal of the American Academy of Neurology. Published continuously since 1951 , it is now a weekly with 48 issues per year. Copyright @ 2018 American Academy of Neurology. All rights reserved. Print ISSN: 0028-3878. Online ISSN: 1526-632X.

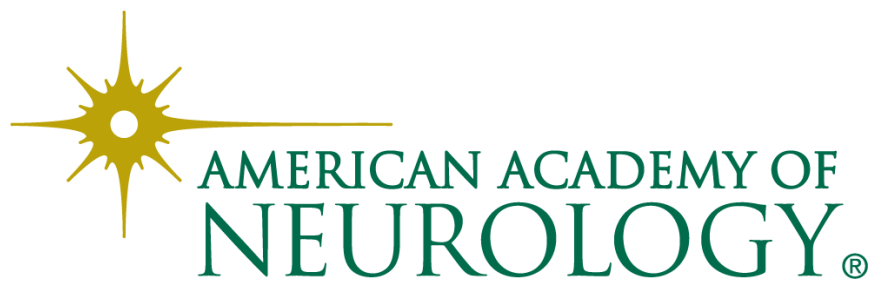

